\title{
FORENSIC ANALYSIS OF BLUNT TRAUMA IN ORAL CAVITY THAT CAUSE THE DEATH: A REVIEW
}

\author{
Ken Sekar Langit ${ }^{1 *}$, Elza Ibrahim Auerkari² \\ ${ }^{1}$ Magister Ilmu Kedokteran Gigi Dasar, Peminatan Odontologi Forensik, \\ Fakultas Kedokteran Gigi, Universitas Indonesia \\ *Email : kensekarlangit09@gmail.com \\ ${ }^{2}$ Departemen Ilmu Kedokteran Gigi Dasar, Peminatan Odontologi Forensik, \\ Fakultas Kedokteran Gigi, Universitas Indonesia \\ *Email : eauerkari@yahoo.com
}

\begin{abstract}
Traumatology is one of the pathology forensic studies to analyze the injury, effect and its relation to the cases of violence of criminals. According to the etiology, its division into four major types of trauma, there are blunt trauma, sharp trauma, gunshot wound, and others. Blunt trauma is a common case in forensic and often becomes the cause of death in many cases, such as accident, homicide, and murderer. Blunt trauma in the oral cavity also can cause death by various mechanisms such as infection, bleeding, and asphyxia.
\end{abstract}

Keyword: blunt trauma, oral cavity, cause of death

\section{INTRODUCTION}

Traumatology in one of the studies in pathology forensic that analyzes the injury, effect, and mechanism of trauma that cause damage to tissue or cause the death. Trauma is meaning for any harm to the body from chemical, mechanical or other energy that outpaces the resistance of the body [1],[2]. According to the World Health Organization (WHO), 1.2 million people died diagnosed by trauma to the head from traffic accidents [3]. A report also informs that 5.8 million younger individuals died with major diagnose as trauma. Its been calculated to increase to 8 million by 2030 [4]. The major complication from trauma is death whether it directly causes death by the damage the vital organ or indirectly complicates the body system then causes hemostasis failure [1]. Based on the etiological, trauma is divided into four main types, blunt trauma, sharp trauma, gunshot wound and others [1],[5-8].

Blunt trauma is a force or injury in the surface of the body by an object that has a blunt angle or surface [9]. Blunt trauma is the most common case in forensic autopsy [1],[4]. Most of the death caused by accidents. It was reported that brain damage as the major cause of death followed by cardiac arrest and aortic damage [4]. Blunt trauma can also happen in the oral cavity for example in murder cases or bullying [1]. Blunt trauma in the oral cavity mostly can't cause death directly but through various mechanisms. The mechanism is through infection, bleeding, and asphyxia [10].

Forensics and forensic odontologist must know the following topic as a reference to analyze the cause of the death in autopsy in trauma patients. In this paper, the authors discuss the blunt trauma, the factors that can make 
blunt trauma cause death and the effect of blunt trauma in the oral cavity.

\section{RESEARCH METHODS}

The literature in this paper was searched in the digital library through Pubmed. The potential journal resources were found in SpringerLink, Wiley Library, ClinicalKey, Science Direct, and Scopus with a time interval between 2000 to 2019 using the following search string: (traumatology * OR blunt trauma*) AND (oral cavity*) AND (effect* OR complication*) AND (cause of death*)

The literature journals then selected by using inclusion and exclusion criteria to determine and gather the potential and relevant reference. The inclusion criteria are:

1. Academic research journal with relevant data;

2. The research journal conclusion is about the following topic;

3. The journal was published with a time interval between 2000 to 2019.

The exclusion criteria are:

1. The journal doesn't have the validity value;

2. The journal topic was irrelevant or doesn't have a complete description;

3. The journal language isn't in English or Indonesian.

The research journal was analyzed and reviewed with the systematical review methode. The result was found in 20 research journals and 3 case reports that have relevant topics in this paper.

\section{DISCUSSION} Trauma
The analysis of forensic is gathering information from physical assessment and internal body. Sign of the wound is the main principle assessment in the patient or victim of trauma. the wound is an injury or discontinues of a tissue such as in skins, soft tissues, muscles, vascular, nerves and bones [9-13]. Based on the etiology of mechanical trauma is divided into four types. There are blunt trauma, sharp trauma, gunshot wound and others such as electrical trauma, radiation or thermal wound [1],[9],[14]. Classification of mechanical trauma from the blunt force is divided into four; abrasion, contusion, laceration, and fracture. On the other hand, sharp force trauma divided into three; incised wound, chop wound and stab wound [14]. A gunshot wound is divided into two; exit wound and entry wound $[8,14]$.

Blunt trauma is a force or injury in the surface of the body by an object that has a blunt angle or surface [9]. Abrasions happen when there is a damage or loss of surface layers of skin. Another type of blunt trauma is contusion which is the extravascular accumulation of blood because of the blood vessel damage without any discontinuity in the outer skin. Laceration happens when there is any rupture or injury of the skin but deeper than abrasion. Fracture in blunt trauma due to breakage of bone by direct or indirect forces [3],[9],[14]. Another type of mechanical trauma is sharp trauma which defines as a wound or injury that causes damage to the body by a sharp object [9]. Incised wound means a clean-cut separation of skin in deeper tissue by sharp 
object or weapon. Chop wound is a clean-cut separation of skin in deeper tissue by a sharp and heavy object. This type of wound mostly becomes the cause of death in many cases. Stab wound or puncture is a piercing wound by a sharp-pointed object [14],[15].

A gunshot wound is an injury caused by bullet penetrating in the body which release by firearm [8]. The entry wound is characterized by an inverted edge and appearance of abrasion. On the other hand, the exit wound has an everted margin [8],[14]. Other etiology of trauma can cause by electrical and thermal. Electrical trauma caused by contact of the body with electric current and it causes the electricity passing through the body then make some effects. Thermal injuries are due to exposure to extreme heat or cold [14].

Trauma can cause death through direct and indirect mechanisms. The direct mechanism means trauma cause death by injury in a vital organ like in many cases of head injury cause brain damage. Whereas indirect mechanism means the trauma causes the malfunctioning organ then make an effect which depends on a few factors that can cause death, especially in blunt trauma [12],[16].

\section{Blunt Trauma as The Cause of Death}

Sharp trauma and gunshot mostly can directly cause death by damaging the vital organ, unlike blunt trauma which depends on a few factors that can cause death. The factors are the pressure of the tool, location, duration and host factor
[7],[12]. The pressure of the tool affects the degree of damage. The experimental study by Isa showed a significant difference in head fractures caused by three different tools. In their research, using the tools with a flat surface (brick), circle surface (stick) and small surface (hammer). The result showed the significant effect of the tool extent the fracture depends on the pressure and the tool surfaces [12]. The result is relevant to other research about duration or frequency. The tool surface might be blunt but when the force achieves the limit of tissue resistant repeatedly, it can cause the damage. At least require $73 \mathrm{~N}$ of force to crack the temporal bone [5],[12].

Location of the trauma can affect the risk because the body has several regions that fragile to injury, for example, oropharyngeal, when it gets injured by the trauma can cause airway obstruction or hemorrhage that can cause death [3],[4]. The host of the trauma means the victim's age and predisposing condition. Children, adult and the elderly have different responses to mechanical trauma. These differences relate to the bone density of the victims. The predisposing condition of the host means a condition that can aggravate the prognosis such as systemic disease or down syndrome [7],[17].

Those are the factors as the reference to finding the cause of death from blunt trauma victims. Blunt trauma in the oral cavity is a rare case but can cause death by various mechanisms. Mostly by three mechanisms; infection, bleeding and asphyxia. 


\section{Infection}

Infection is the most common effect of blunt trauma in the oral cavity. A case report of blunt trauma in the oral cavity caused by bullying. Blunt trauma that caused pharyngeal
This condition created a malfunctioning organ and caused death. Infection occurs due to an injury or an open wound that allows the bacteria to enter and cause the infection [3].

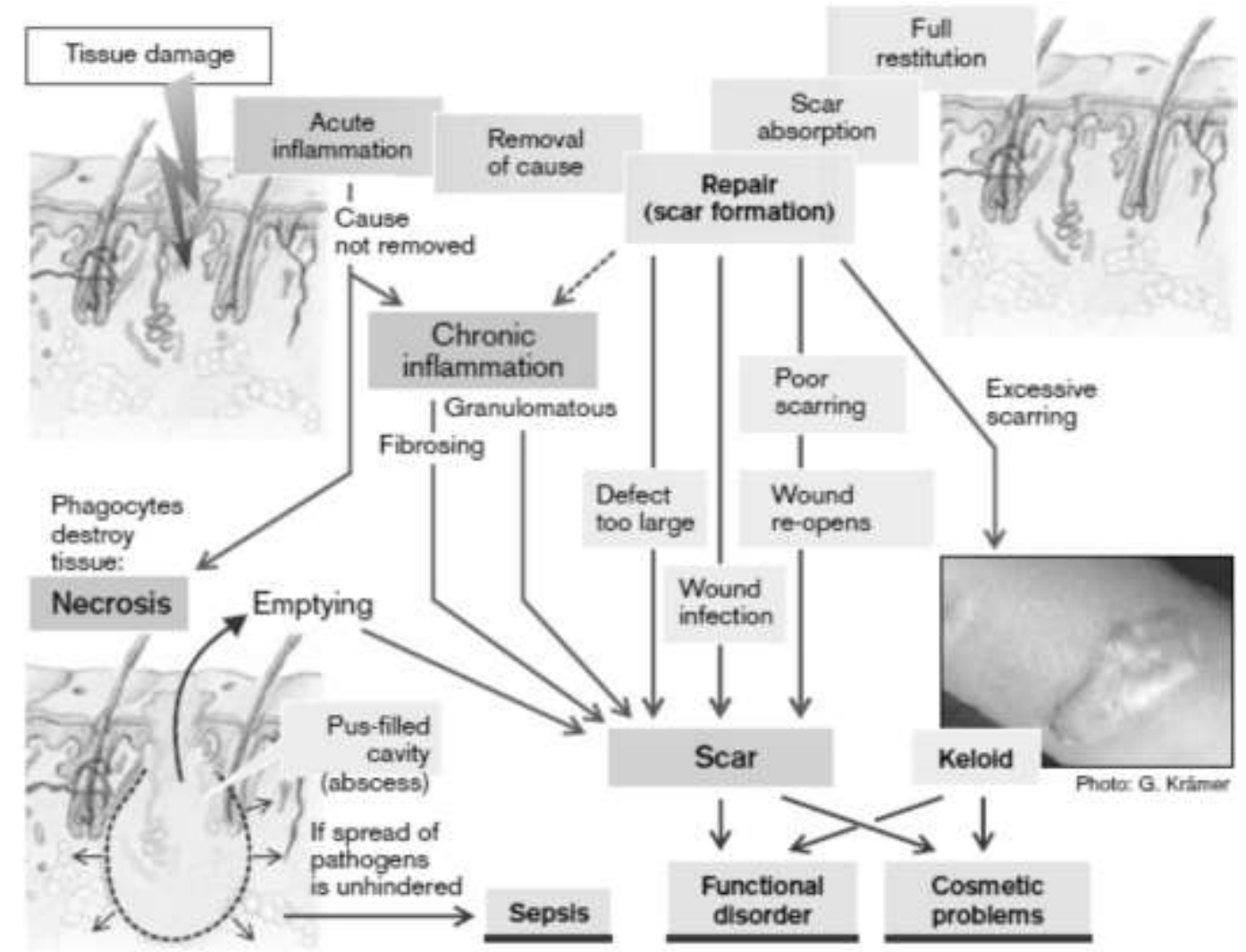

wound and infection. Thus infection impacted the surrounding organ and caused damage to an internal organ.

Figure 1. Inflammation process [18]

Infection condition also leads to inflammation response which one of the reasons is hematoma that can obstruct the airway. Airway obstruction can cause death by asphyxia mechanism. This condition needs an early diagnose to prevent the inflammation obstructs the airways. Blunt trauma can also cause damage in deep organ or tissue, an appropriate antibiotic is needed for the trauma patient. Broad-spectrum antibiotics after post-traumatic infections are possible to increase the prognosis because in the oral cavity many bacteria can become pathogenic [3], [19-22].

\section{Bleeding}

Bleeding under the skin tissue is a sign of the trauma and a mark of violence evidence. Bleeding can also cause death when the blood accumulates on vital organs or blood 
vessels because of the injury. This condition can increase the risk of death. There are many reports about blunt trauma from a traffic accident that caused the death by head injury with the mechanism of death is head trauma. A subdural hematoma is the most common cause of death from a head injury [11].

Accumulation of blood can trigger multiple organ damage. This condition significantly increases the risk. Severe blood loss may produce three response of the body which named triad of death. Triad of death indicates a condition when the body reacts to the massive bleeding. The reactions are coagulopathy, acidosis, and hypothermia which every reaction affects the other's reaction. Early treatment to one of the factors can decrease the risk [15],[23].

Bleeding can happen in the oral cavity for example, in the condition of trauma in carotid arteries by a case of penetrating toothbrush in children. The examination was done immediately then performed vascular surgery [10]. Massive bleeding from intraoral trauma can obstruct airways that need to handle immediately [24].

\section{Asphyxia}

Asphyxia is a condition characterized by disruption of respiratory exchange which amounts to oxygen in the blood is low (hypoxia) and increasing carbon dioxide (hypercapnia). Based on etiology of asphyxia is divide into three; natural, mechanical and intoxication. Natural asphyxia occurs when a disease causes a problem in the respiratory system. Intoxication means a toxin in the human body causes respiratory depression such as barbiturates or narcotics. Asphyxia due to mechanical trauma can be caused the death by a few pathways like airway obstruction and air or fat embolism by the injury [25].

Asphyxia has four stages, stage one is dyspnea. In this stage, the breathing becomes deep and faster, anxious face with bulging eyes, bluish lips, pulse, and blood pressure increases. The second stage is seizure with strong clonic movement through the body, loss of consciousness, relaxation of the sphincter, cyanosis, pulse, and blood pressure still high. Stage three is apnea where the victim unable to breathe caused by respiratory depression, muscle start to limp, loss of reflexes, pupils dilated, blood pressure starts to decrease, breathing started to shallow. This condition occurs within three to five minutes until the last stage. The last stage is the death stage when the body system becomes malfunction and damage [3],[25].

A case report informed after experiencing blunt trauma in the oral cavity, the victim had a high fever for a few hours which subsequently had a seizure. The investigation, in this case, showed that blunt trauma in the oral cavity in this victim caused vascular embolism then triggered asphyxia condition [3].

\section{CONCLUSION}

Traumatology is one of the forensic pathology studies that frequently occur in forensic autopsy. Blunt trauma is the most common case than sharp trauma and gunshot wound or other trauma. It does not only cause injury in surface tissue but also in a deeper organ that needs to immediately examine. There are a 
few factors that influence the severity of injury by blunt trauma which need to analyze in trauma patients or victims.

Blunt trauma in the oral cavity can cause death by a few pathways like infection, bleeding, and asphyxia. Those conditions need to be examined immediately and proper treatment to prevent the risk. The main treatment for trauma is the examination of lifethreatening complications such as airway obstruction and hemorrhage.

\section{REFERENCES}

[1] Awaloei AC, Mallo NTS, Tomuka D. Gambaran cedera kepala yang menyebabkan kematian di Bagian Forensik dan Medikolegal RSUP Prof Dr. R. D. Kandou periode Juni 2015 - Juli 2016. Jurnal eClinic. 2016;4(2):6-10.

[2] Lovich-Sapola J, Johnson F, Smith CE. Anesthetic Considerations for Oral, Maxillofacial, and Neck Trauma. Otolaryngologic Clinics of North America. 2019;52(6):1019-35.

[3] Sawitri R, Andriani. Kematian Akibat Kekerasan Tumpul pada Rongga Mulut. Fatmawati Hospital Journal. 2016;1(7):89-98.

[4] Saar S, Lomp A, Laos J, Mihnovits V, Salkauskas R, Lustenberger $\mathrm{T}$, et al. Population-Based Autopsy Study of Traumatic Fatalities. World Journal of Surgery. 2017;41(7):1790-5.

[5] Afandi D, Herkutanto. Investigasi Forensik pada Kasus Kematian Dugaan Akibat Cedera Kepala. Jurnal
Kedokteran Brawijaya. 2017;30(1):68-75.

[6] Amelinda A, Hoediyanto $\mathrm{H}$, Kalanjati VP. Profil Kasus Pembunuhan Anak di Departemen Ilmu Kedokteran Forensik dan Medikolegal RSUD Dr. Soetomo. e-Jurnal Kesehatan Indonesia. 2018;6(1):50-2.

[7] Hartoyo M, Raharjo SS, Budiyati. Prediktor Mortalitas Penderita Cedera Kepala Berat di Instalasi Gawat Darurat RSU Tugurejo Semarang. POLTEKKES E-Journal. 2012;1(3):175-85.

[8] Umboh RVS, Mallo NTS, Tomuka D. Pola Luka pada Korban Mati Akibat Senjata Api di Bagian Ilmu Kedokteran Forensik Medikolegal FK Unsrat - RSUP Prof. Dr. R.D. Kandoumanado Periode Janurai 2007 - Desember 2013. Jurnal e-Clinic. 2015;3(1):33-9.

[9] Ridwan I, Tambunan JFP. Perdarahan Masif sebagai Sebab Kematian pada Autopsi Kasus Perlukaan. Majority. 2017;6(3):90-5.

[10] Sagar S, Mehra NK, Singhal M, Kumar S, Kumar A. A rare case of life-threatening penetrating oropharyngeal trauma caused by toothbrush in a child. Journal of Indian Society of Pedodontics and Preventive Dentistry. 2010;28(2):134-6.

[11] Case ME. Distinguishing accidental from inflicted head trauma at autopsy. Pediatric Radiology. 2014;44(4):632-40.

[12] Isa MI, Fenton TW, Goots AC, Watson EO, Vaughan PE, Wei F. Experimental investigation 
of cranial fracture initiation in blunt human head impacts. Forensic Science International. 2019;300(8):51-62.

[13] Viswanathan S, Viswanathan S. Physical Injury to Oral Mucosa Following Ingestion of Large Number of Tablets. Indian $J$ Stomatol. 2013;4(2):103-5.

[14] Shetty BSK, Rastogi P, Padubidri JR, Kanchan T, Babu YR. Atlas of Forensic Pathology. New Delhi, India: Jaypee Brothers Medical Publishers; 2014.

[15] Mitra B, Tullio F, Cameron PA, Fitzgerald M. Trauma patients with the 'triad of death'. Emergency Medicine Journal. 2012;29(8):622-5.

[16] Gijwani D, Singh S, Mathur A, Makkar D. Traumatic orofacial injuries and its prevention. Saudi Journal of Sports Medicine. 2017;17(2):70-4.

[17] Kibayashi K. Prevention of head trauma and death in patients with head injuries: A forensic autopsy study. IATSS Research. 2019;43(2):71-4.

[18] Silbernagl S, Lang F. Color Atlas of Pathophysiology. Germany: Georg Thieme Verlag; 2000.

[19] Berkowitz CD. Physical Abuse of Children. The New England Journal of Medicine. 2017;376(17):1659-66.

[20] Feeney JM, Neulander M, DiFiori M, Kis L, Shapiro DS, Jayaraman V, et al. Direct oral anticoagulants compared with warfarin in patients with severe blunt trauma. Injury. 2017;48(1):47-50.
[21] McGraw C, Carrick M, Ekengren F, Berg GM, Lieser M, Orlando A, et al. Severe Fungal Infection Following Blunt Traumatic Injuries: A 5Year Multicenter Descriptive Study. Injury. 2019;50(12):2234-9.

[22] Zaaqoq AM, Namas RA, Abdul-Malak O, Almahmoud $\mathrm{K}$, Barclay D, Yin $\mathrm{J}$, et al. Diurnal Variation in Systemic Acute Inflammation and Clinical Outcomes Following Severe Blunt Trauma. Frontiers in Immunology. 2019;10(4):1526.

[23] Keane M. Triad of death: the importance of temperature monitoring in trauma patients. Emergency Nurse. 2016;25(5):19-23.

[24] Morosan M, Parbhoo A, Curry N. Anaesthesia and common oral and maxillo-facial emergencies. Continuing Education in Anaesthesia Critical Care \& Pain. 2012;12(5):257-62.

[25] Sertaridou E, Papaioannou V, Kouliatsis G, Theodorou V, Pneumatikos I. Traumatic asphyxia due to blunt chest trauma: a case report and literature review. Journal of Medical Case Report. 2012;6(1):257-61. 